\title{
Membership of NATO is the Impulse for Reforms
}

At the meeting of the leaders of NATO states, Lithuania, together with a group of countries of Central and Eastern Europe, was invited to start negotiations regarding membership of this Alliance. Certainly, this is appreciation of our long work we can be happy and proud of our achievements, but we also have to understand that after Prague we will have to do even more. Before the meeting in Prague, we were a reliable partner, after it, we will also have to become a reliable ally. The evaluation of our achieved progress will be based on different criteria.

I said several times and will repeat it in the future that after the invitation, we are going to face hard work. Although the invitation ends up a difficult stage that required a lot of effort, it also means the beginning of another stage - a more complicated one, but certainly more interesting and requiring a lot of responsibility. I have no doubts that we are well prepared to accept all the obligations related to NATO membership.

Our task - becoming a good ally - becomes even more complicated because NATO is in the process of transformation, and this transformation changes the security system of the country and enforces new requirements for the armed forces. All the issues discussed at the Prague summit fall into three main groups: new members, new relationships and new capabilities. All the three aspects have a big influence upon Lithuania's policy.

The admission of new states into this organisation will further strengthen the role of NATO in the world. Lithuania and other invited states will come to NATO with actual economic, social and defensive potential, new thinking and ideas about various aspects of the European defence and security policy that they will stand for as members of NATO and the EU.

The invitation to NATO is not the end of the integration into the Alliance strengthening of security is a continuous process, not a finite act. The consideration of defence policy perspectives of Lithuania as a NATO member must first of all involve international security environment after this stage of enlargement. NATO membership is not only a positive evaluation of our reforms but also a stimulus for further change of our defence system taking due consideration of the reality of our geopolitical position.

There are no doubts that NATO membership will definitely influence relationships of Lithuania with other NATO members as well as the EU and CIS states at 
the same time providing stability and confidence in the erratic world. At the moment, the attention of the world focuses on the new threats, such as terrorism, proliferation of weapons of mass destruction, non-controlled migration, etc. These threats require a new attitude towards them and new capabilities for fighting them. NATO is undergoing transformation and will become a different organisation with new missions and new models of co-operation.

In the face of new threats security became even more related to the development of co-operation, confidence and dialogue. Therefore, we have to further follow open and transparent attitude towards security and defence co-operation in the Baltic region as well as in other regions. The stability and security of the Baltic region has no sense if it does not contribute to the strengthening of European, Euro-Atlantic and global security in the broader sense.

It is evident that Lithuania as a small country with limited economic and demographic resources is not able to implement its foreign and security policy globally alone. This does not mean that Lithuania must not or cannot seek for the role of a regional state. There are two main requirements for this: the first is a rational and pragmatic foreign and security policy, with most effective utilisation of the existing national and public resources for the implementation of national interests; the second is international security environment favourable to Lithuania and respective adaptation of Lithuania to the changing circumstances.

The long-term state development strategy sets out an ambitious goal of becoming the leader of the region. This means playing a more active role in strengthening the security and stability in Europe.

\section{New members - new relationships}

The decision to enlarge NATO was not the only one passed at the meeting in Prague. One of the most important aspects that was stressed during the summit was new relationships with partners. It was decided to develop stronger relationships of a higher quality, and a set of measures for the strengthening of partnership was introduced within the framework of both the Council Euro-Atlantic Partnership and the Mediterranean dialogue, not forgetting the NATO-Russian Council as well as the NATO-Ukraine Commission. Lithuania, being the leader of a successful initiative, the Vilnius ten group - speaks up for a versatile co-operation with partners in the existing as well as new forums.

The determined and well considered policy of Lithuania in respect of Belarus, the Russian Federation, and the Ukraine, also Lithuania's readiness to share its experience of the integration and development of democracy with the Caucasus and Central Asia states that are starting to open to the West with the aim of encouraging those states to further develop relationships with the democratic world, will be Lithuania's successive and continuous contribution to the increasing stability in Europe and outside of it.

Initiatives involving the states of the Caucasus and Central Asia into relationships based on co-operation are especially appreciated. Lithuania is ready to share its experience gained during co-operation projects with the interested states.

Due to the ten years of experience of the Baltic States military co-operation, we have functioning projects and mechanisms for strengthening trust and security. 
This is a basis strong enough for further development of new and strengthening of old relations with countries of other regions. For a long time we were receivers of foreign support. Now it is our turn to share our knowledge and experience gained due to the co-operation with other interested states and regions.

As it was mentioned above, we come to NATO not only with our capabilities. Lithuania's efforts to develop security and military co-operation projects and experience in implementing them will also become part of our contribution to NATO. Our advantage is a well-developed security and military co-operation with many NATO and partner states.

For example, we can mention our participation in the Germany-Poland-Denmark military co-operation triangle; strategic partnership with the USA and Poland, bilateral co-operation with many other states. Projects of military co-operation with Estonia and Latvia supported by the international community deserve extra attention. The whole complex of projects, including BALTRON, BALTNET and BALTDEFCOL, along with the Lithuanian-Polish battalion will form a part of NATO military structures.

Our dialogue with Russia and Belarus aims at enforcing transparency and predictability of relationships with a special focus on the implementation of confidence and security building measures. Priority is given to real work and actions that will develop into greater initiatives later on. Lithuania plans to take an active part in the NATO-Russia Council, and develop bilateral co-operation.

Lithuania has special relations with Kaliningrad region, and successful development of the latter is of special interest to Lithuania. Instability in Kaliningrad region would cause neighbouring countries including Lithuania serious problems associated with smuggling, organised crime, uncontrolled flows of migration and pollution. During the last several years, Lithuania managed to present co-operation with Kaliningrad region as an example of good relations between Lithuania as a EU/ NATO state on the one side and Russia that develops closer and closer relations with these organisations on the other.

As regards Lithuania's relations with Russia, Lithuania took the initiatives that corresponded to its strategy, i.e. to transfer relations between Kaliningrad and Lithuania to a higher level of quality. One of the most important projects to be mentioned was the Nida Initiative (2000) aimed at turning Kaliningrad into a region participating in the regional policy of the EU. This initiative included co-operation projects in a variety of fields ranging from education and culture, to business and investments. Lithuania is the biggest foreign investor in Kaliningrad region and the second state by the number of joint enterprises. Priorities of the co-operation with Kaliningrad region are the co-operation of border protection units, projects related to transport and infrastructure.

The second important element that helps to increase security and stability is the promotion of arms control and weapon non-proliferation. Lithuania understands arms control and non-proliferation as a prerequisite for ensuring international and national security, and signed the most important international treaties regarding arms control and non-proliferation (e.g. the Treaty of Non-proliferation of Nuclear Weapons, the Convention on Chemical Weapons, etc.).

Lithuania considers the Treaty on Conventional Armed Forces in Europe, the CFE Treaty, as an important arms control and confidence and security-building regi- 
me that contributes to the security and stability in Europe. In his speech at the summit of the OSCE that took place in Istanbul in 1999, the President of the Republic of Lithuania V. Adamkus said that Lithuania was considering the possibility of becoming a party of the treaty in case the terms of accession meet our national interests. Lithuania's determination to join the adapted Treaty on Conventional Armed Forces in Europe when it comes into effect and becomes open to all the democratic states of Europe was once again expressed by the President of Lithuania in his speech at the $57^{\text {th }}$ session of the General Assembly of the UN in September 2002.

Also, Lithuania does not directly relate its integration into Euro-Atlantic structures and accession to the adapted CFE treaty. NATO made an official declaration that accession of candidate states to the CFE treaty is not a condition for their admission to the Alliance.

The terms of the future accession of Lithuania to the adapted CFE treaty should not prevent the development of the Armed Forces of our state and hinder interoperability with NATO. Lithuania will seek for non-discriminative membership in the CFE. After the enforcement of the adapted treaty, we will hold consultations with all the parties to the treaty and will be prepared to consider acceptable decisions regarding the terms of membership. Now Lithuanian experts are working to prepare for the practical implementation of the obligations of the treaty in accordance with the requirements of the CFE.

In 2002, Lithuania submitted its request for joining one more important instrument of arms control - the Open Skies Treaty. Expressing its will to join this treaty, Lithuania demonstrated its willingness to strengthen the confidence and security in the region.

The third important principle of Lithuania's security policy is undivided security. On the basis of this principle, Lithuania contributes to international peacekeeping efforts in conflict regions. Since 1994, more than 1,000 Lithuanian military personnel have participated in the NATO-led, UN, OSCE peace operations in Albania, Bosnia-Herzegovina, Georgia, Kosovo. Future plans of Lithuania include the expansion of the participation geography as well as the number of participants in peacekeeping operations. Only participation in international operations with partners and contribution to the efforts of NATO and the EU states to expand democracy and stability in other parts of the world will ensure a solid voice in the decisionmaking process that is important to the country.

Facing full membership in the two most powerful international organisations, Lithuania can with confidence resist the new threats of the 21-st century. The increased co-operation between partners allowed making co-ordinated decisions facing the challenge of terrorism - from the very beginning Lithuania contributed to the antiterrorist coalition proposing some tools for common response. This includes the strengthening of the state border control, the strengthening of anti-terrorist intelligence and counter-intelligence, allowing the USA aircraft to use Lithuanian airspace and airports, proposing to connect the BALTNET system to the analogous NATO system, and the participation of the Armed Forces in anti-terrorist operations.

At the moment Special Forces and military medical personnel contribute to anti-terrorist operations in Afghanistan. A Lithuanian Special Forces platoon (40 persons) participates in the USA-led operation "Enduring Freedom", and a group of military medical personnel in the UN International Security Assistance Forces (ISAF). 
The Special Forces platoon carries out intelligence and patrol functions, and military medical personnel provide medical support to international military personnel as well as local residents in Afghanistan.

The threat of terrorism is mentioned in the National Security Strategy of Lithuania as one of the most important and relevant threats to national security. A growing threat of terrorism makes important such fields as exchange of intelligence data with allies, development of Special forces, development of crisis management and early warning systems, civil-military co-operation. Therefore, in the development of its Armed Forces Lithuania pays more attention to those fields.

\section{New environment - new capabilities}

The development of new capabilities is one of the most important aspects of NATO transformation. The necessity of new forces is dictated by the current situation in the world and emerging traditional and new threats such as international terrorism and the proliferation of weapons of mass destruction. It is evident that the majority of conflicts and disturbances will emerge outside the Alliance; therefore, NATO will need forces different from those that NATO states had ten years ago and that were meant for operations within the territory of the Alliance. Although collective defence remains the main mission of NATO, in the future, the Alliance will more often carry out various crisis management and anti-terrorist operations outside its territory ("out-of-area operations"). To be able to carry out these operations member states are shifting to small but more mobile armed forces with the help of which an effective response to present challenges is possible.

It is not surprising that during the NATO Summit in Prague one of the most important issues was the strengthening of capabilities. The decisions made will have a big influence upon the states aspiring to join the Alliance, in order that their membership would not increase the existing technological gap between the USA and European countries but reduce it in the long-term. With the aim to reserve limited resources "work sharing" exists between NATO countries: each member or the group is "responsible" for capabilities in certain areas. Therefore, the aim is for the countries to strengthen the capabilities that are most necessary for current operations. In Prague NATO countries undertook to enforce capabilities in such areas as transportation of forces by air, precision guided munitions, protection from nuclear, chemical and biological weapons, air surveillance network, etc. Also, the establishment of NATO Response Force was approved in the meeting.

A reliable member, which is the aim of Lithuania, must come to the Alliance with readily developed capabilities necessary for ensuring the security of the country together with allies and contributing effectively to the operations. Membership of the Alliance providing collective defence guarantees enforces a review of defence planning principles of Lithuania: the requirements for Armed Forces are changing in ensuring the defence of the country as well as the implementation of international obligations.

Since the security of the country is ensured on the basis of the principle of collective defence, i.e. in case of crisis or war, allied reinforcements would come to Lithuania, we have to prepare forces that can act together with the forces of NATO countries. There is no need for keeping a big structure of the Armed Forces; it is 
enough to have small, well-prepared and armed, easily deployed and tenable Armed Forces. We are developing not military structures but new types of capabilities necessary for ensuring the security of Lithuania and NATO. Now Lithuania reviews the development of its forces and gives priority to the development of capabilities necessary for acting along with NATO. Only in this way will we be able to use the existing human and financial resources in the most effective way and to achieve the best results for us and for NATO.

The development of a new type of capabilities requires a lot of resources. Lithuania allots 2 percent of gross domestic product for defence, and the money is used for the development of necessary capabilities. The fact that until now Lithuania has been considered as one of the best-prepared candidates to join the Alliance proves that we have achieved good results. Our main principles that were the basis of our work and the reason of our current ability to offer a substantial contribution to the Alliance, are as follows: firstly, determination of strict and realistic priorities of the development; secondly, preparation of specific capabilities needed by the Alliance; thirdly, a successful use of international co-operation mechanisms. We do not intend to withdraw from them in the future.

One of our most important principles is a realistic development of the Lithuanian Armed Forces based on strict priorities. On the one hand, this means that the projection of force development must be accompanied by the evaluation of available resources. On the other hand, we have to develop capabilities to fight threats. In order to effectively use quite limited resources for the implementation of the planned defence reform as well as for a proper preparation for NATO membership, Lithuania complies and will comply in the future with the following main guidelines of the development of the Armed Forces:

- Training of staff and improving of living conditions. This is our main priority. Lithuania aims to increase the number of professionals in the Armed Forces, while the number of conscripts will be reduced. In such a way we seek to improve the professionalism of the Armed Forces. We pay special attention to further improvement of the living conditions of the military in order to attract suitable persons into the Armed Forces;

- Training, readiness and sustainability. This is our second priority. We have to further develop personal and collective training emphasising the training programs co-ordinated with NATO, prepare the necessary infrastructure and procure equipment. While estimating the levels of readiness and requirements of sustainability of different military units we take into consideration the functions attributed to them;

- Modernisation. In the nearest future, we will pay most attention to the modernisation of the military units that are nominated for carrying out operations together with NATO. In the midterm - for the programs related to logistics and sustainability. Also, we will emphasise the development of the existing armament and equipment.

In developing the Armed Forces from the very beginning, Lithuania followed the principle that the basis of the Armed Forces of the country is well-trained and supplied military personnel. Therefore, during the first decade of the development of the Armed Forces, the main focus was the development of training infrastructure, 
improvement of the living conditions of military personnel, ensuring of supply. The profession of the soldier has become attractive for the population of the country.

Only after reaching good results in this field in 2001, the policy of the distribution of financial resources was changed with the increase of the part of defence expenditure for the projects of procurement and modernisation. We aim for Lithuanian armament and equipment to be modern and to meet the goals set for the Armed Forces. Lithuania is implementing six basic procurement projects - air defence systems, anti-tank systems, tactical communication systems, transport, logistics equipment and radar. At the moment 20-25 per cent of the defence budget is allocated for the procurement of modern armaments and equipment. Lithuania signed an agreement with the Government of the USA regarding the acquisition of anti-tank system JAVELIN and is the first country in Europe purchasing these weapons, also an agreement on purchasing the STINGER anti-aircraft system was signed.

The quality of the Armed Forces is determined not by equipment but by welltrained, professional military of high qualification. Therefore, the investment into the training of military personnel remains one of the main priorities. The expenditure for personell in 2002 should amount to 50 per cent of the defence budget - this is an approximate average of NATO countries as well. Already today we have more than 1,000 military and civilian persons, educated abroad even more of them participated in international operations together with the forces of NATO countries. Their preparation and knowledge was positively evaluated by NATO officers. A modern management system of civil and military staff will be introduced in the system of National Defence ensuring the maintenance of specialists of high qualification.

The main motto of Lithuania's integration into NATO has become and will remain the finding of our own "niche" in the structures of the Alliance forces after becoming a competent member of NATO. The participation of Lithuania in international operations shows that it is able to contribute effectively to the operations of the Alliance by providing specialist groups in such fields as military engineering and medicine as well as Special Forces. This should help to share more effectively the burden with other members of NATO facing new security challenges. The mentioned capabilities receive most attention and have already contributed to international operations. In the future, in the course of strengthening its contribution to the Alliance capabilities, Lithuania plans to enforce the development of specific capabilities.

One more way of strengthening effective development of the capabilities is cooperation with foreign partners in implementing joint projects. Lithuania has achieved positive results in this field: these are already the aforementioned projects with the other two Baltic States and LITPOLBAT, a joint battalion of Lithuania and Poland, BALTRON (Baltic Naval Squadron) and BALTNET (Baltic Regional Air Surveillance Network) projects received a very good evaluation from NATO experts. The BALTNET system is already fully interoperable with the NATO air surveillance system and can be connected to the latter within several hours. Preparations for the integration of BALTNET into the NATO air defence system (NATINEADS) are already taking place. We seek for BALTRON to become a part of the NATO naval countermine unit. Lithuania understands that in the future the number of common projects with other countries should increase. Co-operation could develop in various fields, like common procurement of armament and equipment, development of specific capabilities, etc. 
In the course of the preparation of our Armed Forces for the implementation of obligations related to the membership in the Alliance, we have already achieved actual results. We have started the implementation of the reform. Again, realistic plans, based on the existing resources, have become the most important principle of the defence reform. Within the recent years Lithuania has made important decisions regarding the development of the Armed Forces. For example, the planed four combat brigades were reduced to one brigade; 47 battalions of the national defence volunteer forces were reduced to 9 battalion-size reserve units.

At the moment the basis of the Land Forces, the Reaction Brigade, intended for NATO operations in the territory of Lithuania is undergoing a stage of development that will make it fully interactive with NATO in 2006. The Rukla battalion of this brigade is at the moment ready for participation in NATO-led operations outside the territory of Lithuania. Lithuania understands that NATO membership and guarantees of collective security require an effective and solid contribution of Lithuania to the capabilities of the Alliance; therefore, it allots a major part of its resources to the development of the Reaction Brigade. In case of crisis or war in Lithuania, this brigade along with allied forces would carry out combat activities. It is important to ensure our readiness to receive enforcement from allies. Therefore, the main target of the remaining small forces is to ensure the host nations support for allies and to liquidate accidents.

Not long ago, a review of the tasks of the Naval Force and the Air Force has been carried out. Lithuania plans to maintain small Air and Naval Forces necessary for specific tasks, ensuring the sovereignty and territorial integrity of Lithuania as well as the implementation of the Alliance missions. The Air Force will further develop the system of airspace surveillance. Lithuania has identified one of the existing airport partners for the host nation's support; it will allocate investment and aim for assistance from partners in order to achieve that the airport meets all the requirements. The Naval Force will develop countermine forces that will become a part of NATO Naval Forces.

\section{The aim - maintaining the acceleration of reforms}

The success of the Armed Forces reform is closely related to the political and public support for the Armed Forces as well as to NATO integration on the whole. Over 60 per cent of Lithuania's population support NATO integration.

The consensus regarding the integration to NATO is also reached among the main political parties; this is expressed by the agreement on the defence policy signed in 2001. This document consolidates support for priority spheres of the development of the Armed Forces and obligation to allocate not less than 2 per cent of the GDP to the national defence budget. Taking into consideration the country's economic situation the allocation of 2 per cent of GDP is sufficiently optimal financing. We plan to further use this practice and involve the political parties of the country into the dialogue on the issues of defence policy even on a larger scale.

In summary, it can be stated that Lithuania has a realistic plan supported by resources, that follows the development of reliable Armed Forces capable of ensuring the defence of the country and collective defence along with the support of allies.

We do our homework which is not special in any way, but which is very impor- 
tant for Lithuania. Our target was to prepare for the moment when NATO decides to invite Lithuania and to ensure that all essential political, economic, technical and military preconditions are created for a positive decision.

We have already achieved very positive results, but there is still much to be done. The invitation to membership of NATO is the beginning of even a more complex process requiring more effort. Therefore, we are preparing for new challenges already now. We want to become good allies and hope that with the admittance of the new members NATO will become even more effective and important than up until now. 